\title{
THE COMPREHENSION OF THE ORANG RIMBA MUSLIM CONVERTS TOWARDS THE QURAN
}

\author{
Irmawati Sagala \\ Sulthan Thaha Saifuddin State Islamic University (UIN) Jambi \\ irma.sagala@fdi.or.id \\ Aris Dwi Nugroho \\ Sulthan Thaha Saifuddin State Islamic University (UIN) Jambi \\ anugrah1983@yahoo.com \\ Siti Mariah Ulfah \\ Sulthan Thaha Saifuddin State Islamic University (UIN) Jambi \\ ulfahhawasyi76@gmail.com
}

\begin{abstract}
As it happens on various indigenous communities or Komunitas Adat Terpencil (KAT) in Indonesia, Orang Rimba in Jambi converted to religion over the past few decades, especially into Islam as the religion of Malay majority people in Jambi. During the conversion, whether Orang Rimba knows well the Quran as authoritative sources of Islamic doctrine? Explanative qualitative research in Dusun Air Hangat and Dusun Nebang Parah indicates that the older generation of Orang Rimba only knew about the Quran symbolically as a sacred scripture of Islam. In the younger generation, the knowledge of the Quran is growing better by having lessons in reading the Quran and Islamic studies. However, this activity is still inadequate in both quantity and quality and encounters many obstacles so that it requires the support of local government institutions, especially the Ministry of Religious Affairs of Indonesia.
\end{abstract}

Keywords: Orang Rimba, converts, religious practice, Quran.

\section{Introduction}

As the religion has become a universal phenomenon in other societies (Agus, 2007), the religious practice is also an essential need for the indigenous community, Komunitas Adat Terpencil (KAT), including the one in Jambi namely Orang Rimba, or Suku Anak Dalam, or Orang Kubu. Historically, Orang Rimba who lives as the hunters and gatherers groups, since the very beginning have their belief system categorized as animism (primitive religion) which has been passed down through generations of their ancestors. Their belief system, that was originally based on the doctrine of monotheism, then gradually turned into polytheism manifested in many spirits, which were named Dewa, who can save, protect and give welfare to their lives (Reslawati, 2012; Fikri, 2014).

Zuhdi (2014) explained that for Orang Rimba, Dewa is an intermediary of God to convey his doctrine and the norm. But according to them, only people who are alim (pious) called as dukun that can meet and communicate with Dewa. From the dukun, people get their understanding of God. Also, Dewa is also positioned as a symbol that its presence is believed explicitly to be the icon of performing certain rituals, such as; the ritual of besale, bedeki, and bebalas (Berta, 2014, p. 53). According to Berta (2014, p. 53-59), the tradition of animism of Orang Rimba was bound with the belief system or religion which contains a set of ways of life that meet the needs of how they live with nature. In their belief system, a dream is an important reality in connecting between the spirits and God that guide their life in the jungle. 
After the independence of Indonesia, religious conversion has been being a common reality in KAT. Religious conversion occurs along with the changing patterns of residence, where those who are starting to stay settled would change their belief and tend to follow the religion of majority community around them. There are at least three factors that encourage the occurrence of this religious conversion, i.e., firstly, the strategy of adaptation to be integrated with the outer life; secondly, as the impact of the Islamic propagation or Christian missionaries; and thirdly as the impact of liability to include the religion on the Residence card, Kartu Tanda Penduduk (KTP), where having KTP is a precondition to deserve facilities and development programs. The people of KAT had to choose 1 of 6 recognized religions in Indonesia (Persoon, 1989; Berta, 2014, Rappoport, 2004). This phenomenon also occurred in Orang Rimba community. Groups who received resettlement did conversions especially to Islam which is a religion of Malay majority people in Jambi (Persoon, 1989).

Someone who converted to another religion would change his life habits in accordance by the new doctrine because the essence of the religion itself is a bond that must be held and observed by humans in everyday life (Nasution, 2013, p. 2). However, the fact that conversion occurred due to intervention of outside force cause the dynamics of religious practices in the life of indigenous communities. In this case, the scriptures and the missionaries take an important role in understanding the doctrine of religion. In the context of Islam, the Quran and the hadith are vital aspects in religion because both are major sources of Islamic law and teachings (Ramulyo, 2004, p. 45; Nata, 2011). In fact, religious practices often do not touch the substantial aspects but rather attached to rituals mixed with traditions. Some studies on Orang Rimba show that they are still carrying out their old rituals while the Islamic law, private law, in this case, is rarely practiced (Mailinar and Nurdin, 2013; Hidayati, 2017).

This paper discusses the perspective of the Orang Rimba Muslim converts on the Quran; how they interact with Quran and what the urgency of the Quran is in their new life system. Furthermore, it will be elaborated here the possibilities that the government can exercise for empowering the religious life of the Orang Rimba.

\section{Methods}

This paper is written based on field research of 2016 in two dusun using qualitative explanative approach. The first was established in Dusun Air Hangat of the Pematang Kabau village in the Sarolangun Regency, and the last was in Dusun Nebang Parah of Nyogan village in Muaro Jambi Regency. Observation and deep interview were the techniques of data collection. Researchers determined the informants by snowball technique which is the Temenggung, the head of Orang Rimba community, was the key informant. As a comparison analysis, this article also used secondary data about the similar situation in other areas.

\section{Discussion and Results}

Orang Rimba spread out throughout five Regencies of Jambi namely Bungo, Tebo, Sarolangun, Batanghari and Muaro Jambi. Some of them are already settled down and semi-settled, but there are still people who live in a nomadic way especially groups residing in the inside of Taman Nasional Bukit Duabelas (TNBD). There are many theories that explain the origins of Orang Rimba, but generally can be categorized into two groups as well as the theory of the KAT according to Koentjaraningrat (Reslawati, 2012, Muntholib, 2014, p.52-60). The first believes that Orang Rimba are the old Malay race as well as Dayak, Sakai, Nias, Mentawai, Toraja, Sasak, Papua, and Batak that constitute the first wave that migrated to Sumatra. The second 
theory is using folklore, argues that Orang Rimba came to an exile area for some reasons. Muchlas (1975) concluded that Anak Dalam came from three derivatives namely South Sumatera descendants who are generally live in the Batanghari Regency; descendants of Minangkabau who are in Bungo Tebo Regency and most of Mersam District (Batanghari Regency); and the descendants of the Jambi original people in the Air Hitam area, Sarolangun Regency.

Referring to the folk stories about the origins of Orang Rimba, the majority of th is community likely originated from the sedentary groups who then chose to isolate themselves in the forest and adapt to a new environment termed secondary adaptation. These patterns are found in many indigenous communities in America and South and Southeast Asia (Persoon, 1989, p. 508). Only Orang Rimba who are descendants of Jambi original people can be considered to meet with proto Malay theory. This study found specifically that people in the Dusun Nebang Parah believe that they are descendants of Palembang while Orang Rimba in Dusun Air Hangat are descendants of native Jambi. It means that Orang Rimba of the current study was probably the sedentary groups who came from Palembang or proto-Malay.

Demographically, villagers of Desa Nyogan consist of 200 families, and all of them are Muslims. While Desa Pematang Kabau has 70 families, with details: 20 families are Muslims, and 25 families are Christians, and the others still embrace the beliefs of their ancestors. Detailed population data (per inhabitants) are unknown.

\section{Orang Rimba knowledge about Quran}

What knowledge of Orang Rimba Muslim converts to Islam is still limited. In general, hey merely know about Allah is a God, Muhammad are the Prophet, and Quran is the Holy Book of Islam (Mailinar and Nurdin, 2013; Reslawati, 2012). Their Islamic practices are still mixed in with the tradition and tend to be on popular rituals such as weddings and processions of tahlilan (prayer for the deceased). In Dusun Senami III, the people usually held tahlilan for the third night, the seventh, to-40 and 100 of the dead. Meanwhile, the tradition of rituals and the application of customary law such as ritual of sale, spells and more are still being carried out. In the practice of law, particularly in the private law, Islamic law is mixed in with customary law. For example, the marriage ordinance already follows Islamic law, but it is still mixed in with the customs regulations such as the rules about the person with whom someone can marry, and the division of inheritance (Mailinar and Nurdin, 2013; Reslawati, 2012, Hidayati, 2017).

Orang Rimba especially the elder group tends not to think that there is any contradiction between the values of traditions they used to do with Islam. If these symptoms continue to take place, it will fade the status of their religion. Folklore in the community stated that Orang Rimba are descendants of Palembang, and there was a possibility that they were Muslims. Netherlands conquered Palembang for the first time in 1812 in which at that time ruled by the Islamic Sultanate of Palembang who founded in 1659. Therefore, we can presume that majority of the inhabitants of Palembang converted to Islam, as the Royal tradition in the archipelago that religion of the King was the State religion. However, as stated by Marsden (2013, p. 246-340), inland community of Sumatra was generally devout Muslims, but they did not know well the doctrine of Islam itself. While urban areas experienced rapid knowledge development especially after the rise of Islamic renewal movement throughout the 17th and 18th century, the alienated Orang Rimba apprehend Islam stagnantly. This situation could cause abrasion of the Islamic identity of Orang Rimba so that in hundreds of years passed, their generation no longer knew about Islam. 
Observation and interviews show that the interaction of Orang Rimba with the Quran is lack, especially among adults that almost have no interaction with Quran at all. This finding is also occurred in other areas, for instance in Dusun Senami III (Batanghari Regency) and Dusun Plempang (Muaro Jambi Regency) (Mailinar and Nurdin, 2013; Reslawati, 2012). Even so, the informants claimed that they learned the Quran as the scripture of their new religion, Islam. However, on the further, they do not know what the content of the Quran and haven't felt the need to learn them.

However, the comprehension of the community leader related to the content and importance of the Quran as the foundation of life is generally better. Jenang Jalaluddin (2016), le leader of Dusun Nebang Parah, for example, said:

"Kami tau al-Qur'an ko kitab suci agamo Islam. Al-Qur'an iko isinyo galogalo kebaikan".

(We know that the Quran is Islamic Scripture. Quran entirely contains about goodness).

Tumenggung Tarib (2016), the leader of Dusun Air Hangat, stated similar opinion:

"Ajaran dalam Qur'an ko ngajak kebaikan."

(Doctrine in the Quran is inviting to goodness)

In fact, Tumenggung Tarib in Dusun Air Hangat has been aware of the importance of the education of the Quran for their communities. He participated in the formation of the initiate instruction activity for children.

\section{Socialization and Education of Quran for Orang Rimba}

Socialization and education of Quran for Orang Rimba Muslim converts is still precarious, especially the group of older people. Socialization of Quran for older people is only occurred by persons independently and occasionally. In fact, the Ministry of Religious Affairs does not have a program of religious construction of Orang Rimba. The Ministry of Religious Affairs of Jambi provided the aid of 10 million dollars and sent scholars for religious reinforcement of Orang Rimba, but that was all (Reslawati, 2012).

Unlike the conditions in an adult group, the education of the Quran to children is now existing in both of villages since the last few years. Now, Orang Rimba began to change their paradigm. At first, they looked that education as something bad that threatened their cultural customs. Therefore, the school was something taboo to them. Meanwhile, the presence of both empowerment programs of NGOs as well as Governments, and the increased interaction with the community encourge the change of their view about the importance of education to be able to live on a par with the community outside (Baharudin, 2010; Persoon, 1989).

In Dusun Air Hangat the children learn the Quran at the mosque of Jabal Nur, which was initiated and maintained by a teacher named Mbah Turo, a Homesteader from Java. The learning process is conducted every day after praying Maghrib until Isha' prayer. In addition to learning to read Quran, the children also learn basic Islamic sciences such as prayer, daily prayer, and morals. Of the approximately 30 people with ages varying from 3 years to 13 years, 20 persons are children of Orang Rimba.

Mbah Turo carries out the education of the Quran for free. He said:

“...... Itu saya lakukan karena panggilan jiwa, dulu di Jawa saya juga guru ngaji. Seikhlasnya saya lakukan tanpa memungut bayaran baik orang Dusun ataupun orang tua Anak Dalam. Mereka mau menyuruh anaknya mengaji saja itu sudah harus disyukuri. Honor saya ya dari imam Masjid saja dan ada 
THR [uang bonus lebaran, pen], pada saya dari PT. SAL".

(I do it because it calls my soul as I used to be a teacher in Java. I did it without taking any payment from anyone who learns. Having them to ask their children studying the Quran should be grateful. My payments come from the Imam of this Mosque and some addition from PT. SAL).

Meanwhile in Dusun Nebang Parah children learn the Quran in Taman Pendidikan al-Quran (TPA), an institution for learning the Quran, now taken care by Almi Susanti, Zainab, and Siddiqiah. The three of them are local citizens that ever attended an Islamic boarding school located in the province of Jambi. In Dusun Nebang Parah, children also began to learn the Quran and many Islamic sciences in some other villages in the Mestong District such as the Dusun Plempang (Reslawati, 2012). But, some children from families who still adhere to their Rimba tradition, have not been interested or have not been allowed by their parents to participate in learning the Quran. Although there are still many obstacles, education on Quran in two areas of studies are better then the condition of Dusun Senami III. Here, the Quran education was held at the mosque in the village, but not routine. In addition, this village is also hard to access especially if rain comes and causes muddy roads in which both the teacher and student will encounter some problems to do the learning (Mailinar and Nurdin, 2013).

Image: Jabal Nur mosque in Dusun Air Hangat and Ar-Rohmah mosque in Dusun Nebang Parah where children learn the Quran
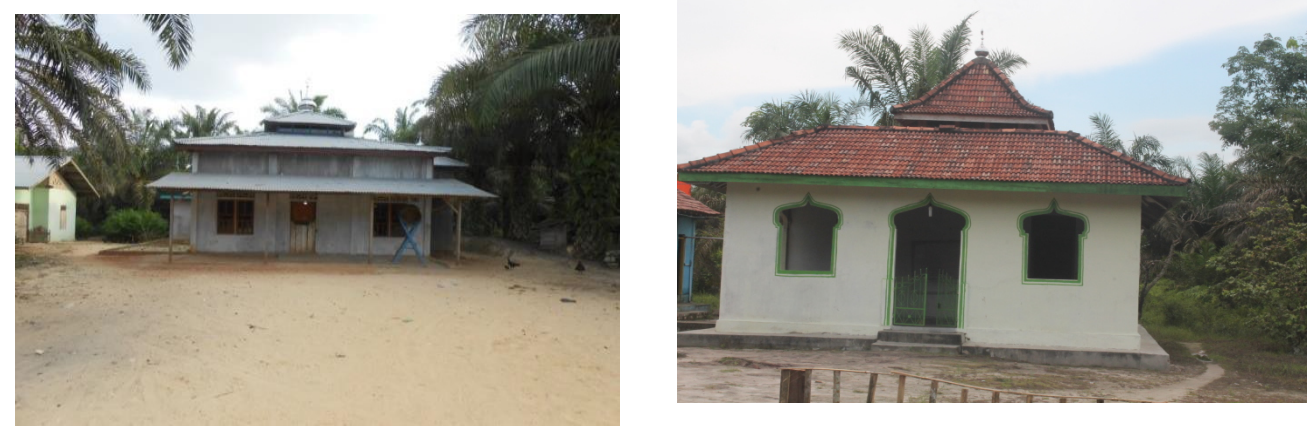

According to Takidin (2014), the melangun tradition has also become its challenges for the learning process includes education of the Quran. In the perspective of culture, we could not perceive this tradition in black-and-white in their impact on the pattern of the new life of Orang Rimba. As part of the custom, the melangun tradition can't be abandoned by Orang Rimba. The Muslim converts in Dusun Nebang Parah have left Melangun tradition. Overall, they have settled in the village. While the Orang Rimba Muslim converts in Dusun Air Hangat in principle has also abandoned this tradition and settled, but they sometimes still practice it in a relatively short time. Therefore, this situation causes another challenge for educators to find the effective methods of learning Quran among their life style.

Quran learning method used is iqra' method with talaqi, the students sit around Mbah Turo then recites the Quran one by one under his supervision. There is no specific curriculum for learning the Quran or Islamic studies. Moreover, Mbah Turo conveys lectures or stories and advice on Islamic teachings.

The capability acceleration in learning of the students of Orang Rimba is also not the same as the other kids in which theirs are at the low level. However, these limitations do not necessarily indicate a lack of intelligence, but it could also come from the weak of literacy in the community and the problems of learning approaches. In 
this case, it seems that Islamic religious educators need to learn from the experience of Butet Manurung when pioneered Sokola Rimba. Butet (2013) stated that in accordance whit the necessities of life and culture of Orang Rimba used the approach of playing with nature, which approached as a means of learning which was packaged flexibly (Manurung, 2013).

\section{Conclusion}

In the development of the belief system of Orang Rimba in Jambi, there has been occurred the phenomenon of religious conversion, particularly into Islam as the religion of Jambi Malay community. Even though this is a fundamental change to their view of life, in which the Orang Rimba previously believed that the Malay people are destined to dwell in villages and to live in the teachings of Islam while the Orang Rimba live in the forest by inheriting the belief system of their ancestors (Sandbukt, 1984), it is not aligned with the increase of their comprehension on Quran where they only know the Quran is the Holy Book of Islam. It could occur that Orang Rimba, especially that found in Dusun Air Hangat and Dusun Nebang Parah, have very minimal interaction with the Quran, especially among older people who almost have no interaction at all. The introduction of the Quran to the elderly only takes place through the religious occasionally outreach programs carried out by a group of people/institution. On the younger generation, the study on Quran started growing better by having lessons in reading Quran and Islamic studies. However, this activity is still inadequate and encountered many constraints, including lack of human resources which are qualified in Islamic teaching that can accompany Orang Rimba for a long time. As one of the proponents of the conversion of Orang Rimba's religion, through inclusion the statement of religion in KTP, the government needs to improve the educational service of the Quran to Orang Rimba community. This service is a consequence of their goodwill in embodying the religious life as contained the first principle of Pancasila and the Constitution of the Republic of Indonesia.

\section{References}

Baharudin, Erwan. (2010). Pendidikan Suku Anak Dalam: Suatu Perubahan dari Paradigma Positivistik ke Konstruktivisme. Forum Ilmiah 7 (2), 100-104.

Berta, Anne Erita Venåsen. (2014). "People of The Jungle": Adat, Women and Change among Orang Rimba. Master thesis submitted to the Department of Social Anthropology, University of Oslo.

Agus, Bustanuddin. (2007). Agama dalam Kehidupan Manusia: Pengantar Antropologi Agama. Jakarta: Rajawali Persada.

Fikri, Ibnu. (2014). Transformasi Teologi Orang Rimba: Pergeseran Kepercayaan Suku Anak Dalam di Wilayah Terap Taman Nasional Bukit Dua Belas Jambi. In Orang Rimba Di Pinggiran Kawasan Hutan Lindung Taman Nasional Bukit XII (TNBD) Provinsi Jambi. Muntholib and Aris Dwi Nugroho (Ed.). Serang: AEmpat.

Mailinar and Bahren Nurdin. (2013). Suku Anak Dalam Religious Life in the Dusun Senami III Jebak Village Batanghari Jambi. Kontekstualita 28 (2), 141-157.

Manurung, Butet. (2013). Sokola Rimba. Jakarta: PT. Kompas Media Nusantara.

Marsden, William. (2013). History of Sumatra (Sejarah Sumatra), trans. Tim Komunitas Bambu. Jakarta: Komunitas Bambu.

Nasution, Harun. (2013). Islam Ditinjau dari Berbagai aspek (Jilid I). Jakarta: UI Press.

Nata, Abuddin. (2011). Studi Islam Komprehensif. Jakarta: Kencana Prenada Media Group. 
Persoon, Gerard. (1989). The Kubu and the outside World (South Sumatra, Indonesia); The Modification of Hunting and Gathering. Anthropos 84. 507-519. http://www.jstor.org/stable/40463938. Accessed: 31-07-2017 08:58 UTC.

Ramulyo, Idris. (2004). Asas-asas Hukum Islam; Sejarah Timbul dan Berkembangnya Keuddukan Hukum Islam dalam Sistem Hukum di Indonesia. Jakarta: Sinar Grafika.

Rappoport, Dana. (2004). Ritual Music and Christianization in the Toraja Highlands, Sulawesi. Ethnomusicology 48 (3): 378-404.

Reslawati. (2012). Dinamika Perkembangan Sistem Kepercayaan Suku Anak Dalam di Kecamatan Mestong Muara Bungo Provinsi Jambi (Kajian Hak-hak Sipil dan Relasi Sosial). In Dinamika Perkembangan Sistem Kepercayaan Lokal di Indonesia. Ahmad Syafi'i Mufid (ed). Jakarta: Balitbang dan Diklat Kementerian Agama RI.

Sandbukt, Öyvind. (1984). Kubu Conceptions of Reality. Asian Folklore Studies, 43 (1), 85-98. http://www.jstor.org/stable/1178100. Accessed: 31-07-2017 09:02 UTC

Takidin. (2014). Nilai-Nilai Kearifan Budaya Lokal Orang Rimba (Studi pada Suku Minoritas Rimba di Kecamatan Air Hitam Provinsi Jambi). Sosio Didaktika 1 (2), 161-169.

Zuhdi, Nurdin. (2014). Tuhan, di mana Kau Berada?; Kajian Etnografi tentang Sistem Kepercayaan Orang Rimba di Taman Nasional Bukit Dua Belas Jambi. In Orang Rimba Di Pinggiran Kawasan Hutan Lindung Taman Nasional Bukit XII (TNBD) Provinsi Jambi. Muntholib dan Aris Dwi Nugroho (Editor). Serang: AEmpat. 